\title{
Why and How Stories Matter in Treating Children with T1DM-Best Practice from CDiC
}

\author{
Sanjay Kalra ${ }^{1}$ Rishi Shukla ${ }^{2}$ Shuchy Chugh ${ }^{3}$ Dinakaran P. ${ }^{4}$ \\ ${ }^{1}$ Department of Endocrinology, Bharti Research Institute of \\ Diabetes \& Endocrinology (BRIDE), Karnal, Haryana, India \\ 2Department of Diabetes Education, Market Access \& Public Affairs, \\ Regency Hospital Ltd., Kanpur, Uttar Pradesh, India \\ ${ }^{3}$ Department of Diabetes Education, CDiC India, Bangalore, \\ Karnataka, India \\ ${ }^{4}$ Department of Market Access \& Public Affairs, CDiC India, \\ Bangalore, Karnataka, India
}

\begin{abstract}
Address for correspondence Dr Shuchy Chugh, Diabetes Education Specialist, Department of Diabetes Education, Novo Nordisk India Private Ltd., Plot No.32, 47-50, EPIP Area, Whitefield, Bangalore 560 066, India (e-mail: scch@novonordisk.com).
\end{abstract}

J Soc Health Diab 2021;9:e15-e18.

\begin{abstract}
Type 1 diabetes mellitus (T1DM) is a lifelong disorder that mostly happens any time during childhood. It needs constant care and attention. Self-management becomes very essential as there are multiple factors that influence management of blood glucose levels and good outcomes. Diabetes education ${ }^{1}$ is essential for this and it involves the process of providing the person with the knowledge and skills needed to perform diabetes self-care, manage crises, and to make lifestyle changes to successfully manage their life. It begins with teaching of survival skills and continues with higher learning to fit diabetes into lives of people with diabetes rather than changing the lives to manage diabetes. Although parents are responsible for this initially, children must be part of this learning and journey as they are the one who must deal with diabetes in their life.

Although knowledge transfer from scientific (truth and fact based) and narrative story (experience and meaning based) is fundamentally different but narrative or stories are

Keywords

- type 1 diabetes mellitus

- diabetes education stories

- motivation

- good habits better absorbed and retained. Storytelling and experience sharing are rapidly developing fields in medical education, but its potential has yet to be realized in medical education. The Changing Diabetes in Children program focused at reaching out to the economically underprivileged children with T1DM has implemented the use of stories to help the T1DM child learn to take insulin injections and understand the basic do's and don't's for proper diabetes management and motivate them to become self-reliant and independent adults in long run.
\end{abstract}

\section{Introduction}

Type 1 diabetes mellitus (T1DM) is an autoimmune disorder and can affect people at any age, but usually develops in children or young adults. People with T1DM need daily insulin injections to manage their blood glucose levels. If people with

DOI https://doi.org/ 10.1055/s-0041-1731095 ISSN 2321-0656
T1DM do not have access to insulin, they will die. ${ }^{2}$ Along with taking insulin, people with T1DM regularly need to monitor blood glucose levels and balance activity and food choices. More than 1,110,100 children are living with T1DM worldwide and around 1,71,000 children and young adults less than 20 years with T1DM in India. ${ }^{3}$ When properly treated, 
children with T1DM can grow like normal individuals and be useful contributors to society and live long lives.

\section{Challenges for Children with Diabetes}

T1DM is a lifelong disorder. Diabetes management is $24 \times 7 \times 365$ job that requires major lifestyle changes along with regular insulin and monitoring to reduce the risk of both short- and long-term complications. Daily life activities like traveling, attending a party, having acute illness like cough and cold, having exams along with hormones, stress, and efficacy of medicine are few of the multiple causes that can affect blood glucose levels. Families need help to cope with the condition, while learning about diabetes and its management. It is essential for child to learn to take self-insulin injection, monitor sugar levels at home and adjustments in diet and exercise to keep blood sugar levels near normal. Adding to this, it was realized later that many parents and children registered in Changing Diabetes in Children (CDiC) program were illiterate.

Education and counselling are the keystones of diabetes care and structured self-management education is the key to a successful outcome. ${ }^{4}$ It is a survival skill essential for children and families of children with T1DM. It begins with teaching of survival skills and continues with higher learning to fit diabetes into lives of people with diabetes rather than changing the lives to manage diabetes. To be effective, diabetes education must be performed in a child-friendly way so that they understand and adapt it.

\section{Story Telling}

We are and become the stories we tell ourselves and our children. Stories are not only important part of Indian culture but all ancient civilizations. They are part of evolution, understanding, learning, and motivation contributing to our cultural, social, mental, and thus physical well-being. Stories play a vital role in life development and formation of goals for both children and adults. For children, stories play an important role as characters they get to know through stories either fictitious or real can become like friends and they want to become like them.

To deal with any health condition, information and education are essential. Engaging through stories usually helps the most reluctant learner to understand and learn. In fact, few researchers have found that the weakest readers and writers are often the one who benefit most from the storytelling. ${ }^{5}$ Health or illness stories (narrative) for that matter any story make themselves available to consciousness because they support many viewpoints the viewpoint of the person, their caretakers, healthcare providers, and even society. In words of prostate cancer patient Anatole Broyard, ${ }^{7}$ doctors are ${ }^{7}$ storytellers who "can turn our lives into good or bad stories, regardless of the diagnosis" (p53) and also added that "any meaning of illness is better than none." (p65)

No doubt, stories allow children to gain maximum opportunity understand and adapt their condition that also includes their life with diabetes along with medical procedures like taking insulin, monitoring while remaining a child. Other benefits to the child include:

- Informative yet inspirational.

- Better conversation and understanding of technical term and procedures.

- Reduction in stress and feeling of being alone.

- Better relationship between child and doctor or educator.

- Enabling child and parents to express their feelings.

- Self-ensuring, target reminder, and reassurance for both children and parents.

Table 1 Story telling has been utilized earlier at many instances

\begin{tabular}{|c|c|c|c|c|c|c|}
\hline Name & Author & Year & $\begin{array}{l}\text { Type of } \\
\text { manuscript }\end{array}$ & $\begin{array}{l}\text { Subject } \\
\text { population }\end{array}$ & Story used & Results/conclusions \\
\hline $\begin{array}{l}\text { Health stories } \\
\text { as connec- } \\
\text { tors and } \\
\text { subjectifiers }\end{array}$ & $\begin{array}{l}\text { Arthur W. } \\
\text { Frank }\end{array}$ & 2006 & Essay & & & $\begin{array}{l}\text { Health stories offer people bits } \\
\text { of a subjectivity of health: an } \\
\text { awareness of what is interior, } \\
\text { expressed in signs that are } \\
\text { exterior }\end{array}$ \\
\hline $\begin{array}{l}\text { Constructing } \\
\text { identities } \\
\text { through } \\
\text { storytelling } \\
\text { in diabetes } \\
\text { management }\end{array}$ & $\begin{array}{l}\text { Lena } \\
\text { Mamykina, } \\
\text { Andrew } \\
\text { D. Miller, } \\
\text { Elizabeth } \\
\text { D. Mynatt, } \\
\text { Daniel } \\
\text { Greenblatt }\end{array}$ & 2010 & $\begin{array}{l}\text { Original } \\
\text { manuscript }\end{array}$ & $\begin{array}{l}\text { First-Newly diag- } \\
\text { nosed individuals } \\
\text { with diabetes } \\
\text { Second- } \\
\text { Experienced peo- } \\
\text { ple with diabetes. } \\
\text { Both were regular } \\
\text { attendees of dia- } \\
\text { betes education } \\
\text { classes }\end{array}$ & $\begin{array}{l}\text { MAHI (Mobile Access } \\
\text { to Health Information), } \\
\text { helped individuals with } \\
\text { diabetes record their } \\
\text { diabetes experiences } \\
\text { and take appropriate } \\
\text { decisions through social } \\
\text { interaction with diabetes } \\
\text { educators and other peo- } \\
\text { ple in similar situation. }\end{array}$ & $\begin{array}{l}\text { Stories help patients in three } \\
\text { ways: the need to maintain a } \\
\text { positive self-image, the need to } \\
\text { re-affirm individuals' compe- } \\
\text { tency in managing the disease, } \\
\text { and the need to maintain a } \\
\text { continuity in one's self-image } \\
\text { and a link with their self before } \\
\text { the disease }\end{array}$ \\
\hline $\begin{array}{l}\text { A Narrative } \\
\text { Approach } \\
\text { to Healing } \\
\text { Chronic Illness }\end{array}$ & Egnew TR & 2018 & Review & & & $\begin{array}{l}\text { Stories are a good tool to pro- } \\
\text { mote acceptance and meaning } \\
\text { for lives of people suffering from } \\
\text { any illness. Suffering to some } \\
\text { extent can be transcended } \\
\text { through stories of people in } \\
\text { similar condition }\end{array}$ \\
\hline
\end{tabular}




\section{Evidence Base Details on Use of Story Telling}

- Table 1

\section{Changing Diabetes in Children (CDiC) Program}

In an attempt to address the critical gap in the management of diabetes in India, Novo Nordisk Education Foundation, in collaboration with the International Society for Pediatric and Adolescent Diabetes, had launched $\mathrm{CDiC}$ program in 2011 with the objective of giving children below the poverty line access to comprehensive diabetes care and management. As part of the program, more than 5000 children are provided with free insulin, diagnostic tests, monitoring, and diabetes education.

\section{CDiC and Stories}

MISHTI (Mishti means sweet) CDiC program began with the story of Mishti. Mishti is a story of a little girl with diabetes who shares her journey with T1DM. Four booklets and one digest along with few others comic panel as a part of other patient education magazines released so far.

\section{Brief Description}

Mishti-1 speaks about basic understanding of T1DM. The journey of diagnosis through a child's eyes and how she feels, her hopes and dreams. This book also creates awareness about signs and symptoms of T1DM.

Misthi-2 emphasizes children with T1DM should play, exercise, and involve in physical activities. It is story about Mishti participating in sports day and attending Christmas party. These include instructions for the child with diabetes while doing any exercise or participating in any sports activity.

In Mishti-3, the story revolves around Misthi going on a school trip. This focuses on debugging myth that children with T1DM cannot be independent. This also includes safety instructions for the child with diabetes to be followed while traveling.

In Mishti-4, Mishti talks about things to be followed during any acute illness.

All these stories are translated in 10 Indian languages to increase the reach and understanding to all the children in different parts of the country.

This was followed by Mishti Digest in 2017 that contained three stories on how Mishti made exercise a fun activity, how she helps her friends with diabetes to enjoy the party, and a story that explains how simple things make children with diabetes emergency ready.

Along with this, Mishti comic panels continue in CDiC newsletter and Prerana where Mishti shares the tricks of living with diabetes with other children and adults with diabetes.
Mishti offered multiple benefits, namely:

1. Providing both information and inspiration.

2. Helping the child to be a friend with another child with diabetes.

3. Understanding about taking insulin, insulin injection sites, and overcoming fear.

4. Giving the basic understanding about diabetes in simple words.

5. Understanding and planning for diabetes self-management in various situations of life.

6. Keeping the learning with themselves to reread and relearn.

7. Dispelling myths and misconceptions about T1DM.

Mishti video offers multiple benefits, namely:

1. Helping very small children and illiterate patients and their parents.

2. Teaching of children while they are waiting to meet doctor.

\section{Qualitative Research}

Mishti was distributed to every child enrolled in CDiC program. It was appreciated by our beloved former President late Dr. APJ Kalam. A 8-year-old child with diabetes told, "Mishthi is my best friend. She also has diabetes like me." According to another child, "If Mishti can come first in her class, so, I also can?" Diabetes educator at one of the CDiC centers wrote, "Mishti is a cute gift for all children with type 1 diabetes. We were motivating a girl to study and learn basic reading and write. What we could not do, Mishti could do." Father of a child with T1DM said, "Mishti depicts smiling face which shows we should be always positive thinking \& good attitude." According to Dr. Sanjay Kalra, CDiC Center Director, Karnal, "It helps break the ice; brings a smile to the child's face."

\section{Translational Research}

Diabetes management is a daily chore. Each choice related to food and physical activity can affect the blood glucose of people living with diabetes. Life is a matter of story. Same story may seem heroic to one and tragic to another, but it effects the person. For some, it provides understanding; few understandings come with internalization and feeling of companionship and there is a bunch of people who gets motivated and lessons from the learning of the story.

\section{Conclusion}

Stories are no doubt a fun activity but also an effective way of communication, preserving facts, providing knowledge, and understanding and yet giving motivation and morale to live a better life. There is no other way apart from stories that can give information, education, and motivation in simple words. Stories are a useful approach that can help in establishing a dynamic relationship between the child and the therapist, 
supporting in their learning process for self-management, especially in chronic diseases like diabetes.

\section{Conflict of Interest}

None.

\section{Reference}

1 Clement S. Diabetes self-management education. Diabetes Care 1995;18(8):1204-1214

2 Atkinson, M. A., Eisenbarth, G. S. \& Michels, A. W. Type 1 diabetes. Lancet 383, 69-82 (2014).
3 Idf atlas ninth edition; 2019 https://www.diabetesatlas.org/ upload/resources/material/20200302_133351_IDFATLAS9efinal-web.pdf

4 Phelan H, Lange K, Cengiz E, et al. ISPAD Clinical Practice Consensus Guidelines 2018: Diabetes education in children and adolescents. Pediatr Diabetes. 2018;19(Suppl. 27):75-83. https://doi.org/10.1111/pedi.12762

5 National Council of Teachers of English: Position Statement from the Committee on Storytelling https://ncte.org/ statement/teachingstorytelling/

6 Frank AW. Health stories as connectors and subjectifiers. Health (London) 2006;10(4):421-440

7 Broyard A, Intoxicated by My Illness. New York, NY: Fawcett Columbine; 1992 